\title{
Further Observations on the Lichen Genus Strigula in New Zealand
}

\author{
EmmanuËl SÉRUSIAUX \\ Research Associate F. N. R. S., Department of Botany, Sart Tilman B22, B-4000 Liège, Belgium
}

Abstract. Six species of the lichen genus Strigula are reported from New Zealand: S. delicata Sérus. sp. nov. S. fossulicola P. M. McCarthy et al., S. nemathora Mont., S. novae-zelandiae (Nag Raj) Sérus. comb. nov. (Basionym: Discosiella novae-zelandiae Nag Raj), S. oceanica P. M. McCarthy et al., and S. subtilissima (Fée) Müll. Arg.

In 1983, the late J. K. Bartlett deposited a large set of foliicolous lichens he had collected in New Zealand in the LG herbarium. Although poorly curated, the material was prolific and has yielded several new taxa: the type collection of Enterographa bartlettii Sérus. (1984), Badimiella serusiauxii Malcolm \& Vězda a monotypic genus with spectacular campylidia (Malcolm \& Vězda 1994; Sérusiaux 1986), and the recently described Strigula kaitokensis Sérus. \& Polly (1996). For some time, I was aware that several other undescribed species of Strigula, not mentioned in the monograph of Santesson (1952), were present in the material. Two have now been described by McCarthy et al. (1996) from Lord Howe Island (Australia) and are here recorded for the first time from New Zealand; another species appeared to be identical with the anamorphic lichenized fungus Discosiella novae-zelandiae Nag Raj (1981) and is here transferred to Strigula, and an additional one is here described as new. A new species of Mycomicrothelia, amazingly similar to a genuine Strigula, has also been found in the collections and is described as new in a separate paper (Sérusiaux \& Aptroot 1998).

New Zealand appears to be rich in species of Strigula, with several new species and new records reported (Hafellner \& Kalb 1995; Harris 1995; McCarthy 1995; McCarthy \& Malcolm 1996; Sérusiaux \& Polly 1996). However, the genus is still poorly known at the world level so it is too early to claim that New Zealand is a center of diversity. More work is needed before a global assessment can be made.

The taxonomic concept of the genus Strigula has been reorganized by Harris $(1975,1995)$ to include all foliicolous species referred by Santesson (1952) to that genus, Raciborskiella Höhnel, the so-called Porina phyllogena group (= Phylloporis Clem.), and several corticolous and saxicolous species, previously included in Arthopyrenia Massal. and Porina Müll. Arg. All these species have the same type of asci, paraphyses, and conidia. This concept is accepted here as such a genus is clearly mono- phyletic, even if one expects that further detailed studies may lead to the segregation of several smaller genera within that clade.

All collections mentioned in this paper have been gathered by the late J. K. Bartlett $(\dagger 1986)$ and are housed in LG. Representative samples are deposited in B, CANB, CHR, and herb. R. Lücking.

\section{Strigula delicata Sérusiaux $s p$. nov. (FIg. 1-2} \& $7, \mathrm{a}-\mathrm{b})$

Thallus epiphyllus, subcuticularis, plus minusve circularis, 2-5 mm diam., pallide viridis vel olivaceo-brunneus, nitidus, laevigatus, lobis angustis (ca $0.1 \mathrm{~mm}$ latis) et dichotomis formatus, interdum connatis et reticulum formantibus; margo cum continua vel interrupta, nigra linea et numerosis, parvulis, elongatis nigrisque papillis. Algae ad Cephaleuros pertinentes. Perithecia in parvis, circularibus thalli maculis crescentia, ad marginem locatis, hemisphaerica, $0.2-0.25 \mathrm{~mm}$ diam. et $0.10-0.18 \mathrm{~mm}$ alta, nigra et nitida; paraphyses numerosae, ramosae et leviter anastomosantes; asci clavati, 55-60 × 10-14 $\mu \mathrm{m}$; ascosporae $8 /$ ascus, biseriatae, ellipsoideae ad fusiformes, 1-septatae, $15-16(-18) \times 4.5-5.0 \mu \mathrm{m}$, pariete crasso $(0.7-1.0 \mu \mathrm{m})$. Macroconidia oblonga, 1-septata, appendicibus mucosis, 3-5 $\mu \mathrm{m}$ longis et terminalibus praedita, 13-16 $\times 3.0-3.5$ $\mu \mathrm{m}$; microconidia ellipsoidea, ca $3 \times 1 \mu \mathrm{m}$.

Thallus epiphyllous, subcuticular, occurring or not along the nerves, margins, and scars of leaves, \pm circular, 2-5 mm in diam., usually quite abundant, pale green or olive brown (white when dead), shiny but without any metallic tint, with smooth surface, formed of dichotomously branched, narrow (ca $0.1 \mathrm{~mm}$ wide) lobes that can fuse laterally and form a reticulum; lobes margins with discontinuous or continuous black line and usually with numerous, rather regularly scattered, small, elongate, black papillae. Photobiont a species of Cephaleuros (Trentepohliaceae), with \pm rectangular or rounded cells, 8-15 $\times$ 4-7 $\mu \mathrm{m}$, yellowish green, \pm arranged in radiating rows. Perithecia usually present and abundant, typically occurring in center of small, circular (0.3-0.6 mm in diam.) patch of thallus with small and rounded lobes located at or near lobes tips, single or paired (rarely in $3 \mathrm{~s}$ ), typically hemispheric, never (ob-)conical, with rounded apex, 

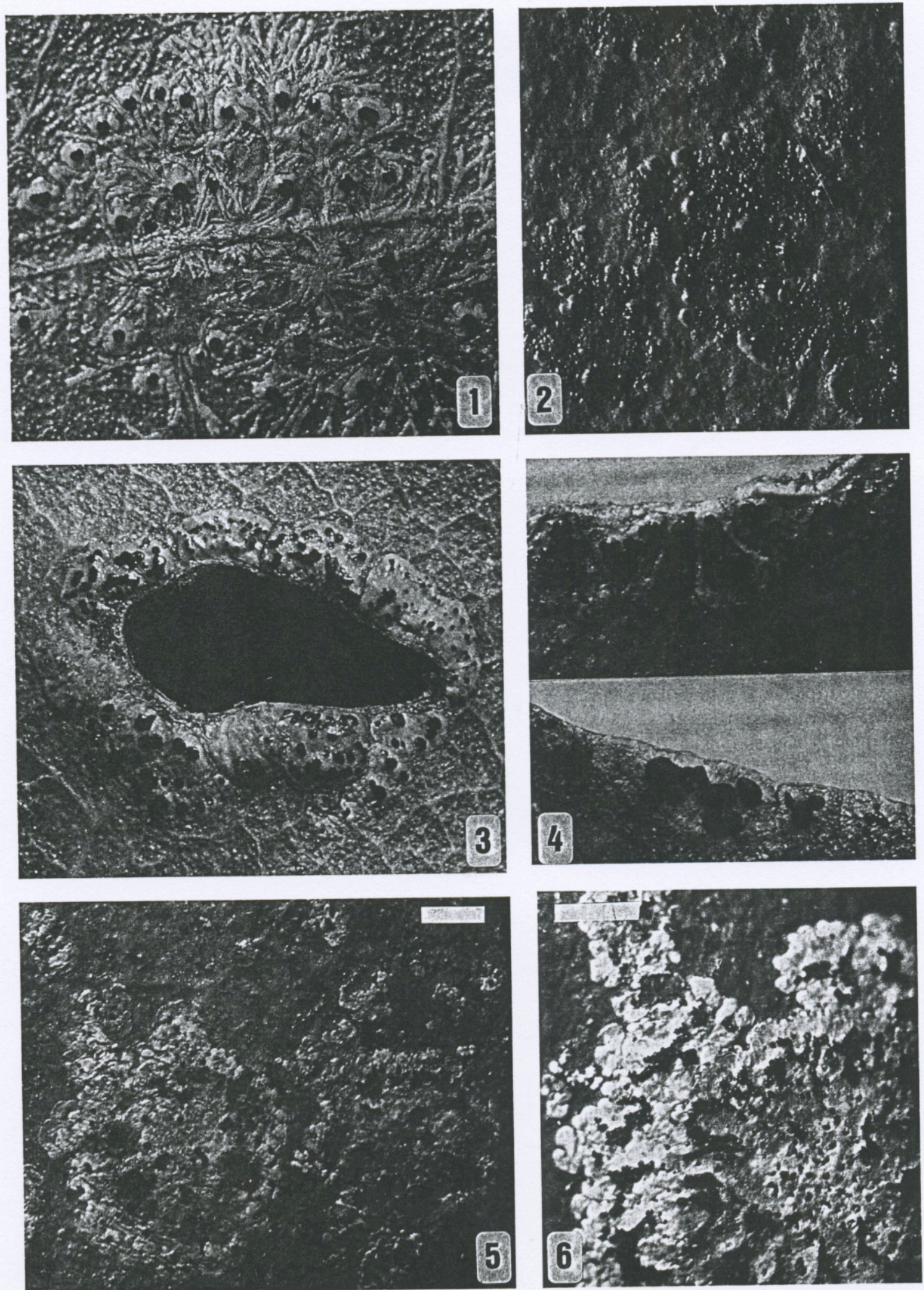

FIGURES 1-6. Habit of Strigula species from New Zealand. - 1. S. delicata, morph 1 (Bartlett 18616). - 2. S. delicata, morph 2 (holotype). - 3. S. fossulicola (Bartlett 18573). - 4. S. oceanica (Bartlett 18579). - 5-6. S. novae-zelandiae (Bartlett s. n., Auckland, 17. VI. 1979). Scale $=0.1 \mathrm{~mm}$ (scale for $1-5$ shown only on Fig. 5). 


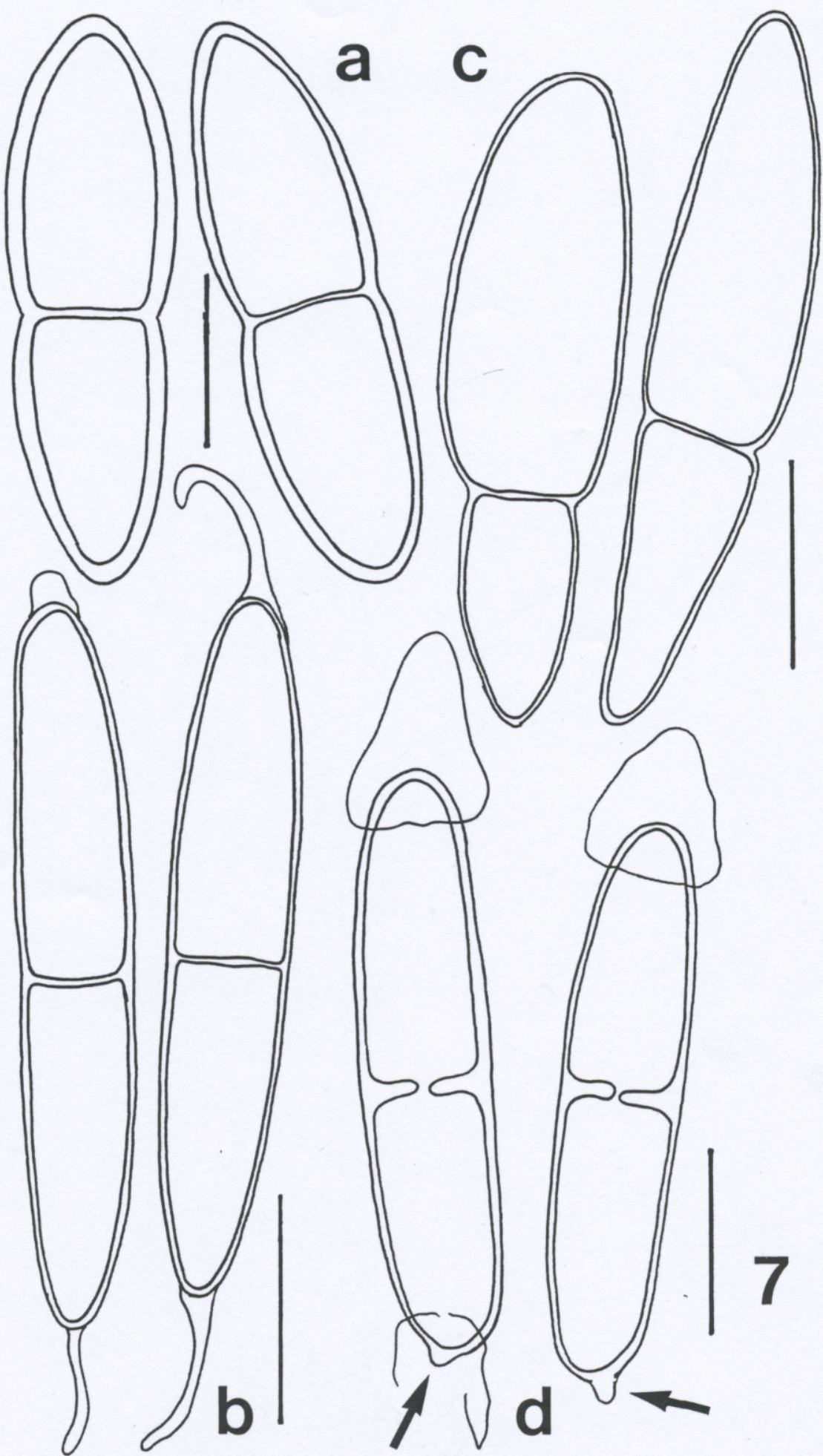

FIGURE 7. Ascospores and macroconidia of Strigula delicata (holotype) and $S$. novae-zelandiae (Bartlett $s$. n., Auckland, 17. VI. 1979). - a-b. S. delicata. - c-d. S. novae-zelandiae. Scale $=5 \mu \mathrm{m}$. Arrows in d point to the sublateral protuberance at the proximal end of macroconidia. 
black and usually shiny, $0.20-0.25 \mathrm{~mm}$ in diam. and $0.10-0.18 \mathrm{~mm}$ high, immersed in thallus up to at most $1 / 3$ of total height, with central, scarcely distinct ostiole; outer wall and involucrellum black in section, heavily carbonized, $28-40 \mu \mathrm{m}$ thick near ostiole; involucrellum not or hardly expanding laterally; outer wall absent under perithecial cavity; inner wall pale brown, hardly distinct; perithecial cavity $120-140 \times 160-180 \mu \mathrm{m}$; hamathecium of abundant paraphyses that are branched and sometimes anastomosed, ca $1 \mu \mathrm{m}$ thick, with several transverse septa; asci bitunicate, clavate, 55-60 $\times$ $10-14 \mu \mathrm{m}$, with thickened apex that contains small ocular chamber; ascospores 8 per ascus, biseriate, ellipsoid to fusiform, with rather rounded ends, 1septate, slightly constricted at septum, with rather thick-wall $(0.7-1.0 \mu \mathrm{m})$, the proximal cell slightly more elongate, not breaking into pieces and without any mucoid appendage, $15-16(-18) \times 4.5-5.0 \mu \mathrm{m}$. Pycnidia producing macroconidia black and nitidous, flattened to hemispheric, ca $0.1 \mathrm{~mm}$ in diam., single or aggregated in groups of $2-3(-4)$ that can be distinctly elongate, typically developed at the tips of lobes; conidiogenous cells lining bottom of pycnidial cavity, cylindric or slightly inflated at their base; macroconidia oblong, with rounded ends, 1-septate, not or slightly constricted at septum, 13-16 × 3.0-3.5 $\mu \mathrm{m}$, with mucoid, elongate, 3-5 $\mu \mathrm{m}$ long appendage at both ends (sometimes missing at one end) that may be terminated by a hook. Pycnidia producing microconidia appearing as tiny black points at margins of thallus, or included in pycnidia producing macroconidia; microconidia ellipsoid, \pm deformed, with rounded ends, ca $3 \times 1 \mu \mathrm{m}$.

TYPE: NEW ZEALAND. NoRTH ISLAND. Erua, near National Park, on shrub, Bartlett 18579, 16. XII. 1977 (LG, holotype; CANB, CHR, isotypes). NEW ZEALAND. NORTH IsLAND. Church Road Scenic Reserve, near Kaitaia, Mangonoui $\mathrm{Co}$, on leaves in old bush remnant, Bartlett 18616 and s. n., 8. IV. 1982. Herekino Gorge near Ahipara, on old trees in forest margin, on leaves of Beilschmiedia, Bartlett 18612, 14. VIII. 1979. Ngaiotonga Saddle, Bartlett $18575,18615,14$. VIII. 1976 (LG, all paratypes).

Strigula delicata is easily distinguished by a thallus composed of dichotomously branched lobes that may form an attractively patterned reticulum, hemispheric perithecia developed on tiny and circular islands of thallus at the extremities of the lobes, ascospores with thick-walls, and the rather long macroconidia $(13-16 \times 3.0-3.5 \mu \mathrm{m})$. Two different growth forms have been recognized in the material examined: one with dichotomously branched and sparingly anastomosed lobes and a pale green thallus (Fig. 1); the other with a more compact thallus forming an attractive reticulum due to the anastomosing lobes and a olive brown thallus (Fig. 2). As the perithecia, asci, ascospores, and conidia are identical in the two forms, there is no reason to consider that two taxa are involved. Indeed, these differences in morphology are most probably due to different mechanical characteristics of the host leaves, especially their cuticle.

The other foliicolous species of Strigula with a thallus bordered by a thin black line are easily distinguished by their thallus morphology, the shape of perithecia, and size and shape of ascospores and macroconidia (Santesson 1952): all have a dark green thallus and rather acute to conic perithecia, and none has ascopores with a thickened wall. Strigula subtilissima (Fée) Müll. Arg. has a reticulate thallus, ascospores that are fusiform to bacilliform, 10-16 $\times 2-3 \mu \mathrm{m}$, and macroconidia measuring 4-7 $\times 2 \mu \mathrm{m} ; S$. maculata (Cooke \& Massee) R. Sant. has a more compact thallus, fusiform to bacilliform ascospores, $12-18 \times 2.5-4.0 \mu \mathrm{m}$ and macroconidia, $4-6 \times 1.5-2.0 \mu \mathrm{m} ; S$. melanobapha (Krempelh.) R. Sant. has a thallus with almost free lobes (and thus rather similar to forms of $S$. delicata), fusiform ascospores with acute ends, 14-22 $\times 3-5 \mu \mathrm{m}$, and macroconidia, $10-12 \times 3-5 \mu \mathrm{m}$.

Strigula fossulicola P. M. McCarthy, Streimann \& Elix, Lichenologist 28: 240, 1996.

(FIG. 3)

This very typical species has been described from Lord Howe Island (Australia) and is here reported for the first time from New Zealand, where it has been found at several localities on the North Island. It forms semi-circular thalli with small rounded lobes near margins or wounds of the leaves on which it grows. The perithecia are almost entirely immersed, and the small, clavate asci (28-35 $\times 5.5-7.0 \mu \mathrm{m})$ and small ascospores $(8-10 \times 2.0-$ $2.5 \mu \mathrm{m}$ ) which break into two pieces within the asci are very characteristic.

Specimens examined.-NEW ZEALAND. NORTH IsLAND. Auckland, Ravensthorpe, on leaves of Beilschmiedia, Bartlett s. n., 17. X. 1980; $30 \mathrm{~km} \mathrm{~N}$ of Auckland City, on leaves, Bartlett s. n., 14. XI. 1979; Ngaiotonga Saddle, on leaves of Beilschmiedia, Bartlett 18573, 14. VIII. 1976; Pukekawa, Raglan Co, on leaves of Alectryon excelsa, Bartlett 18601, 17. V. 1980. Strigula nOvaE-Zelandiae (Nag Raj) Sérusiaux
comb. nov.
(FIG. 5-6 \& 7, c-d)

Discosiella novae-zelandiae Nag Raj, Can. J. Bot. 59: 2528. 1981. TYPE: NEW ZEALAND. NORTH ISLAND. Papakura, Kirk's bush, on leaves of Beilschmiedia, Kendrick KNZ 32, 20. XII. 1973 (PDD 40205, holotype!).

Thallus epiphyllous, subcuticular, almost never growing near the margins and scars of leaves, typically and almost perfectly circular, 3-6(-10) $\mathrm{mm}$ in diam., usually very abundant, pale green to ash 
green (white when dead), shiny but without any metallic tint, with smooth or slightly irregular surface; margin always with rounded, $0.1-0.3 \mathrm{~mm}$ wide, sometimes deeply digitated, lobes which give the thallus its typical crenulate appearance, 40-50 $\mu \mathrm{m}$ thick, without prothallus. Photobiont a species of Cephaleuros (Trentepohliaceae), with \pm rectangular to rounded cells, 8-20 $\times 4-7 \mu \mathrm{m}$, yellowish green, \pm arranged in rows. Perithecia few in collections examined, but numerous on thalli on which they are present, slightly flattened but with rather hemispheric or slightly conic apex, single or rarely aggregated in groups of 2(-3), typically arranged in circle, at first immersed in thallus but soon with more than half of the outer surface exposed, black or greenish when still covered by thallus, smooth, rather shiny, $0.25-0.35(-0.4) \mathrm{mm}$ in diam. and ca $0.2 \mathrm{~mm}$ high, with central, usually distinct ostiole. Outer wall and involucrellum carbonaceous black in section, expanding laterally under thallus and thus reaching $0.5-0.6 \mathrm{~mm}$ in diam., $25-35 \mu \mathrm{m}$ thick near ostiole; inner wall pale brown, less than 10 $\mu \mathrm{m}$ thick; perithecial cavity rather flattened, 0.30 $0.34 \mathrm{~mm}$ in diam. and ca $0.1 \mathrm{~mm}$ high; hamathecium of simple or sparingly branched paraphyses, ca $1 \mu \mathrm{m}$ thick, with several transverse septa; asci bitunicate, obclavate, with thickened apex that contains small ocular chamber, 55-60 × 10-12 $\mu \mathrm{m}$; ascospores 8 per ascus, biseriate, fusiform, at first with acute ends but in maturity with rather rounded ends, 1-septate, usually with distal cell enlarged and somewhat swollen in mature stages, not breaking into pieces and without any mucoid appendage, 16$18(-22) \times(3.0-) 4.5-5.0 \mu \mathrm{m}$. Pycnidia producing abundant macroconidia, even on thalli producing perithecia and sometimes even overgrowing them, circular, $100-130 \mu \mathrm{m}$ in diam., single or most frequently aggregated in linear or irregular groups of $2-10$, hemispheric, black and shiny, with central, distinct ostiole; conidiogenous cells lining bottom of pycnidial cavity, cylindric or slightly inflated at base; macroconidia abundant, sometimes protruding from pycnidium as a cylindric whitish cirrus, subapically produced, subcylindric (ellipsoid to almost bacilliform) with rounded ends, proximal end with typical obconic, sublateral protuberance and distal one with cap- or fan-shaped mucoid appendage, 1-septate, with septum typically and always thickened (1.0-1.5 $\mu \mathrm{m}$ thick) leaving central pore between two cells, not constricted at septum, 13$17 \times 3.0-4.5 \mu \mathrm{m}$. Pycnidia producing microconidia not found.

Strigula novae-zelandiae is easily distinguished by its circular thalli with a crenulate to deeply digitated margin, and especially its numerous pycnidia producing polarilocular macroconidia. It is the only species in the genus with such a thick septum sep- arating the two cells of its macroconidia; the septum is always perforated in its center and thus the macroconidia can be described as polarilocular and look like ascospores of the well-known genus $\mathrm{Cal}$ oplaca.

This species was first described by Nag Raj (1981) in the genus Discosiella H. \& P. Sydow, a genus that represents the anamorph of Strigula. Article 59.1 of the International Code of Botanical Nomenclature does not permit the so-called dual nomenclature for lichenized fungi; however artificial and irrelevant such a provision may be, it forces the epithet novae-zelandiae to be transferred to the genus Strigula. The new combination is thus made here. The type collection has been examined and is identical in all respects with the collections here referred to $S$. novae-zelandiae; it does not produce any perithecia.

Nag Raj (1981) has provided a detailed description of the conidiogenesis and our observations are in accordance with his, except for one point: he claims that a mucoid appendage is present at both ends of mature macroconidia. In all species of Strigula, the macroconidia are embedded in a closely appressed mucoid shealth; in mature stages, this shealth usually remains as an appendage at both extremities, either as a cap- or fan-shaped one [e.g., in S. affinis (Massal.) Harris, and most corticolous or saxicolous species] or as a long, filiform one [e.g., in S. nitidula Mont. and many foliicolous species; see Roux and Bricaud (1993) for further examples of these mucoid appendages]. In $S$. novaezelandiae, the mucoid appendage develops its final shape only at the distal end, while it is never seen at the proximal one where only fragments of the original mucoid shealth can be observed. An obconic, sublateral protuberance is easily observed at the proximal end: such a protuberance is rarely seen in any other species in the genus.

Specimens examined.-NEW ZEALAND. NORTH IsLAND. Auckland City, Titirangi, at sea level, Bartlett 18590, 15. VI. 1979; Auckland, in dense bush, on dead leaves of Beilschmiedia collected on the forest floor, Bartlett s. n., 17. VI. 1979; Auckland, Ravensthope, near Bombay Hill, in bush remnant, on leaves of Beilschmiedia, Bartlett s. n., 17. X. 1980; Church Road Scenic Reserve, near Kaitaia, Mangonoui Co, on leaves in old bush remnant and on tawa, Bartlett 18591 (dupl. in PDD), 18879, 18880, 8. IV. 1982; $30 \mathrm{~km} \mathrm{~N}$ of Auckland City, on leaves, Bartlett s. n., 14. XI. 1979; Coastal forest near Orewa, $30 \mathrm{~km} \mathrm{~N}$ of Auckland, on leaves of Beilschmiedia, Bartlett s. n., 14. XI. 1979.

Strigula oceanica P. M. McCarthy, Streimann \& Elix, Lichenologist 28: 242, 1996.

(FIG. 4)

Strigula oceanica is the second species described by McCarthy et al. (1996) from Lord Howe Island (Australia) and is here reported from New Zealand 
for the first time, having been found on both the North and South Islands. It forms rounded thalli with radiating grooves near leaf margins and scars and is easily characterized by its very long, subcylindric asci $(92-110 \times 6-8 \mu \mathrm{m})$ and its ascospores measuring $13-16 \times 3.8-5.0 \mu \mathrm{m}$ and which separate into two pieces in the asci.

Specimens examined.-NEW ZEALAND. NORTH IsLAND. Erua, near National Park, on shrub, Bartlett 18570, 16. XII. 1977; Church Road Scenic Reserve, near Kaitaia, Mangonoui $\mathrm{Co}$, in old bush remnants, on tawa, Bartlett 18875 , 8. IV. 1982. South IsLAND. Makarora River near Haast Pass, on leaves of Pseudowintera colorata, Bartlett 18583 , 4. XI. 1981.

Strigula nemathora Mont. and S. Subtilissima (Fée) Müll. Arg.

Besides the species mentioned above and the recently described S. kaitokensis Sérus. \& Polly, two further, well-known, pantropical species have also been identified in the material examined: $S$. nemathora Mont. (NEW ZEALAND. NORTH IsLAND. Church Road Scenic Reserve, near Kaitaia, Mangonoui $\mathrm{Co}$, in old bush remnants, on tawa, Bartlett s. n., 8. IV. 1982) and S. subtilissima (Fée) Müll. Arg. (NEW ZEALAND. NORTH IsLAND. Ngaiotonga Saddle, Bartlett 18615, 14. VIII. 1976).

\section{ACKNOWLEDGMENTS}

I wish to thank very warmly the curator of the PDD herbarium in New Zealand, E. H. C. McKenzie, for the loan of the type collection of Discosiella novae-zelandiae, $\mathrm{J}$. Lambinon for his help in reviewing this manuscript and for valuable comments, and the late J. K. Bartlett for making the collections available.

\section{Literature Cited}

Hafellner, J. \& K. Kalb. 1995. Studies in Trichotheliales ordo novus. Blibliotheca Lichenologica 57: 161186.

HARRIS, R. C. 1975. A taxonomic revision of the genus Arthopyrenia Massal. s. lat. (Ascomycetes) in North America. Ph.D. dissertation, Michigan State University, East Lansing.

1995. More Florida lichens, including the $10 \notin$ tour of the pyrenolichens. New York, privately published.

Malcolm, W. M. \& A. VĚzdA. 1994. Badimiella serusiauxii, a new genus and species of foliicolous lichens from New Zealand (Ectolechiaceae). Nova Hedwigia 59: 517-523.

MCCARTHY, P. M. 1995. New saxicolous species of Strigula Fr. (lichenised Ascomycotina: Strigulaceae) from Australia and New Zealand. Muelleria 8: 323-329.

\& W. M. Malcolm. 1996. Strigula occulta, a new saxicolous lichen from New Zealand. Mycotaxon 60: 323-326.

- H. Streimanx \& J. A. Elix. 1996. New foliicolous species of Strigula from Lord Howe Island, Australia. Lichenologist 28: 239-244.

NAG RAJ, T. R. 1981. Genera Coelomycetum. XIX. Discosiella, a lichenized mycobiont. Canadian Journal of Botany 59: 2519-2533.

Roux, C. \& O. BRICALD. 1993. Studo de la genro Strigula (Lichenes, Strigulaceae) en S-Francio. Graveco de la macrokonidioj. Bulletin de la Société linnéenne de Provence 44: 117-134.

SANTESSON, R. 1952. Foliicolous lichens I. A revision of the obligately foliicolous, lichenized fungi. Symbolae Botanicae Upsalienses 12(1): 1-590.

SÉRUSIAUX, E. 1984. New species or interesting records of foliicolous lichens. Mycotaxon 20: 283-306. 1986. The nature and origin of campylidia in lichenized fungi. Lichenologist 18: 1-35.

- \& A. APTROOT. 1998. Mycomicrothelia striguloides sp. nov. from New Zealand. THE BRYOLOGIST 101: 144-146.

\& B. Polly. 1996. Strigula kaitokensis sp. nov. from New Zealand. Mycotaxon 59: 245-251.

ms. received July 24, 1997; accepted Nov. 18, 1997. 